\title{
The Investigation of the Evaluation on Competitiveness of Joint-Stock Commercial Banks
}

\author{
Hong Yin \\ School of Business \\ Sichuan University \\ Chengdu, China 610065
}

\begin{abstract}
The competitiveness of commercial banks are own stronger profitability than its competitors under the condition of regulated operation. This dissertation is aiming to research some aspects of the competiveness among the jointstock commercial banks, large state-owned commercial banks and city commercial banks, and further analysis the own situation of joint-stock commercial banks. The research showed that Joint-stock commercial banks showed an outstanding performance on its profitability and growth ability the innovation ability, growth rate was faster than state-owned commercial banks. It is very important to enhance the innovation ability of intermediary business for improving the competitiveness of the joint-stock commercial banks.
\end{abstract}

Keywords-competitiveness of commercial banks; innovation ability; Factor analysis; joint-stock commercial banks

\section{INTRODUCTION AND BACKGROUND}

With the deepening develop of global financial, the big banks from around the world flood into China's financial market. Since China executed banks mixed operation, commercial banks' business tend to be diversified, which in turn increases the competition between them, commercial banks in China face double competition from domestic and foreign banks. Now, our country banking system changed from "monopoly" situation into the pattern of "diversification", the quantity, type and size of banks are growing. Large state-owned commercial banks have been in a leading position because of the strong comprehensive strength, city commercial banks have a certain advantage in the regional features, joint-stock commercial banks in recent years develop rapidly. Compared with the large state-owned commercial banks and city commercial banks, what's the competitiveness of joint-stock commercial banks? Did they develop steadily? This problem is worthy of discussion.

For the definition of commercial banks' competitiveness, Yang Jiacai defined the competitiveness of commercial banks as the banks continue to achieve more profit than other rivals by actively manage risk and do business. Mester et al. found that $\mathrm{X}$ efficiency is the key factor of business efficiency and competitiveness of commercial banks. Joaquin et al. thought management level and product innovation capability are the key to improving competitiveness of commercial banks. Dietrich and Wanzenried et al. found that operating efficiency, loan growth and financing cost is the main factor to boost competitiveness.

Domestic scholars used may methods to research the competitiveness of commercial banks, Wang Jiaquan referred to the camels rating system, designed the competitiveness indicators of listed banks in China, including the external competitiveness and potential competitiveness evaluation index. Chi Guotai analyzed the competitiveness of the big four state-owned commercial banks by principal components analysis, and put forward some suggestions to enhance the competitiveness of stateowned commercial banks. Fang Xianming designed competitiveness system based on the three basic indicators of commercial banks, through the empirical study found that the competitiveness of large state-owned commercial banks is stronger, but this advantage is diminishing.

By studying a large number of domestic related literatures found that most of the papers studied the comprehensive competitiveness of different types of commercial banks, very few compared the specific competitiveness factors. On time to chosen; only one year of data is studied, and the contingency factors are very large. On the basis of research results of domestic and international papers, this essay evaluates the competitiveness of jointstock commercial banks from five aspects: the liquidity, profitability, market share, and growth and innovation ability, and uses factor analysis model to analyze the relevant data from 2011 to 2013 of 15 listed commercial banks in China.

\section{RESEARCH METHOD AND V ARIABLE SELECTION}

\section{A. Research Method}

This article adopts the method of empirical study, uses the model of factor analysis, which is more objective and comprehensive than others methods. The principle of factor analysis is synthesizing the original variables which have complicated relationship into a few unrelated common factors. Each public factor extracts much of the information of the original variables, so it is good representative. Factor analysis remains the advantages of principal component analysis; it also can carry on the concrete explanation of each public factor. This article uses SPSS20.0 for factor analysis. 


\section{B. Sample Selection}

This article preliminary selects 16 listed commercial banks as the research object, in 2011 Shenzhen Development Bank acquired 90.25\% stock from Ping An Bank, thus its annual report was combined statements, which makes it not comparable. So we eliminate Ping An Bank. In the paper, we study 15 listed commercial banks, including five state-owned commercial banks, seven joint-stock commercial banks and three city commercial banks.

\section{Variable Selection and Data Sources}

The data of this essay are from Wind, "China financial yearbook" and the annual reports released by different commercial banks.

Commercial banks' competitiveness is the comprehensive results of various aspects shown by banks, so the selection of indicators should both include the realistic and potential competitiveness indicators. Considering the operational principle and importance principle, this paper sets up 5 general indexes and 13 specific indexes. Specific indicators analyses are in following table:

TABLE I. COMMERCIAL BANKS' COMPETITIVENESS EVALUATION INDEX

\begin{tabular}{|c|c|c|c|}
\hline $\begin{array}{l}\text { Indicators } \\
\text { category }\end{array}$ & Index name & Letter & Calculation method \\
\hline \multirow[t]{2}{*}{ Liquidity } & liquidity ratio & $X_{1}$ & $\begin{array}{l}\text { Liquid assets/Liquid } \\
\text { liability }\end{array}$ \\
\hline & $\begin{array}{l}\text { Asset-liability } \\
\text { ratio }\end{array}$ & $X_{2}$ & Liability/Assets \\
\hline \multirow[t]{3}{*}{ Profitability } & $\begin{array}{l}\text { Cost-income } \\
\text { ratio }\end{array}$ & $X_{g}$ & $\begin{array}{l}\text { (operating expenditure- } \\
\text { Sales Tax and Extra } \\
\text { Charges)/Operating } \\
\text { income }\end{array}$ \\
\hline & Return on assets & $\mathrm{X}_{4}$ & $\begin{array}{l}\text { Net profit/Average assets } \\
\text { of the beginning and end } \\
\text { year }\end{array}$ \\
\hline & $\begin{array}{l}\text { Return on } \\
\text { Equity }\end{array}$ & $\mathrm{X}_{5}$ & Net profit/Owner's equity \\
\hline \multirow{3}{*}{ Market share } & Deposit share & $X_{6}$ & $\begin{array}{l}\text { Deposit/Total deposit of } 15 \\
\text { banks }\end{array}$ \\
\hline & Loan share & $X_{7}$ & $\begin{array}{l}\text { Loan/Total loan of } 15 \\
\text { banks }\end{array}$ \\
\hline & $\begin{array}{l}\text { Total assets } \\
\text { share }\end{array}$ & $X_{8}$ & $\begin{array}{l}\text { Total assets/Total assets of } \\
15 \text { banks }\end{array}$ \\
\hline \multirow[t]{2}{*}{ Growth } & $\begin{array}{l}\text { Operating profit } \\
\text { growth rate }\end{array}$ & $\mathrm{X}_{9}$ & $\begin{array}{l}\text { Operating profit } \\
\text { growth/Operating profit at } \\
\text { the beginning of the year }\end{array}$ \\
\hline & $\begin{array}{l}\text { Total assets } \\
\text { growth rate }\end{array}$ & $X_{10}$ & $\begin{array}{l}\text { Total assets growth /Total } \\
\text { assets at the beginning of } \\
\text { the year }\end{array}$ \\
\hline \multirow[t]{3}{*}{$\begin{array}{l}\text { Innovation } \\
\text { ability }\end{array}$} & $\begin{array}{l}\text { Percentage of } \\
\text { bachelor or } \\
\text { above employee }\end{array}$ & $\mathrm{X}_{12}$ & $\begin{array}{l}\text { Bachelor degree employees } \\
\text { and above /Total number of } \\
\text { employees }\end{array}$ \\
\hline & $\begin{array}{l}\text { Percentage of } \\
\text { fee and } \\
\text { commission } \\
\text { income }\end{array}$ & $X_{13}$ & $\begin{array}{l}\text { Fee and commission } \\
\text { income/Operating income }\end{array}$ \\
\hline & $\begin{array}{l}\text { Fee and } \\
\text { commission } \\
\text { income growth } \\
\text { rate }\end{array}$ & $X_{11}$ & $\begin{array}{l}\text { Fee and commission } \\
\text { income growth/Fee and } \\
\text { commission income at the } \\
\text { beginning of the year }\end{array}$ \\
\hline
\end{tabular}

In this index system, there are both positive and reverse factors, asset-liability ratio and cost-income ratio are reverse indicators. We adopt the method to change reverse into positive: $X^{\prime}=1-X$, where $X^{\prime}$ is positive variables, $\mathrm{X}$ is the original variables.

\section{EXPERIMENTAL}

\section{A. Factor Analysis}

Considering the limited space, we only list the analysis process of year 2013, year 2011 and 2012 only use text to explain. The VAR00001 VAR00013 as following respectively represent variables presented in "table I".

\section{1) Common factor analysis}

TABLE II. TOTAL VARIANCE EXPLAINED

\begin{tabular}{|c|c|c|c|c|c|c|}
\hline \multirow{2}{*}{$\begin{array}{c}\text { Com } \\
\text { pone } \\
\text { nt }\end{array}$} & \multicolumn{3}{|c|}{ Initial Eigenvalues } & \multicolumn{3}{|c|}{$\begin{array}{c}\text { Rotation Suns of Squared } \\
\text { Loadings }\end{array}$} \\
\hline & Total & $\begin{array}{l}\text { Varian } \\
\text { ce\% }\end{array}$ & $\begin{array}{l}\text { Accumul } \\
\text { ation \% }\end{array}$ & Total & $\begin{array}{l}\text { Varianc } \\
e \%\end{array}$ & $\begin{array}{c}\text { Accum } \\
\text { ulation } \\
\%\end{array}$ \\
\hline 1 & 6.274 & 48.260 & 48.260 & 4.894 & 37.645 & 37.645 \\
\hline 2 & 2.155 & 16.573 & 64.834 & 2.391 & 18.394 & 56.039 \\
\hline 3 & 1.420 & 10.924 & 75.758 & 1.996 & 15.350 & 71.389 \\
\hline 4 & 1.278 & 9.834 & 85.592 & 1.733 & 13.332 & 84.721 \\
\hline 5 & 1.076 & 8.277 & 93.868 & 1.189 & 9.147 & 93.868 \\
\hline 6 & .379 & 2.916 & 96.785 & & & \\
\hline 7 & .201 & 1.544 & 98.328 & & & \\
\hline 8 & .097 & .749 & 99.077 & & & \\
\hline 9 & .069 & .528 & 99.605 & & & \\
\hline 10 & .049 & .379 & 99.984 & & & \\
\hline 11 & .001 & .011 & 99.995 & & & \\
\hline 12 & .001 & .004 & 99.999 & & & \\
\hline 13 & .000 & .001 & 100.000 & & & \\
\hline
\end{tabular}

It can be seen from the table above that for year 2011, the variance accumulation contribution rate of the forth principal components is $86.126 \%$, and the rate for 2012 is $88.620 \%$. 
For 2013, the variance accumulation contribution rate of the fifth principal components is $93.868 \%$, all of them have surpass $85 \%$, which shows that the principal components of each year can describe comprehensive competitiveness of commercial banks perfectly.

\section{2) Name the common factor}

TABLE III. ROTATED COMPONENT MATRIX

\begin{tabular}{|l|r|r|r|r|r|}
\hline \multirow{2}{*}{ Variable } & \multicolumn{5}{|c|}{ Component } \\
\cline { 2 - 6 } & $\mathbf{1}$ & $\mathbf{2}$ & $\mathbf{3}$ & $\mathbf{4}$ & $\mathbf{5}$ \\
\hline VAR00006 & .955 & .154 & .215 & .070 & .032 \\
& & & & & \\
\hline VAR00008 & .944 & .174 & .219 & .075 & .056 \\
\hline VAR00007 & .939 & .185 & .202 & .118 & .059 \\
\hline VAR00012 & -.912 & -.239 & -.079 & .137 & .031 \\
\hline VAR00011 & -.885 & -.174 & .177 & -.302 & -.019 \\
\hline VAR00013 & .092 & .777 & .568 & .017 & -.084 \\
\hline VAR00009 & -.325 & -.773 & -.282 & .374 & .132 \\
\hline VAR00010 & -.343 & -.767 & .264 & -.056 & -.205 \\
\hline VAR00005 & .132 & -.021 & .921 & -.258 & -.035 \\
\hline VAR00004 & .415 & .268 & .701 & .398 & .238 \\
\hline VAR00001 & .084 & -.150 & -.075 & .930 & -.125 \\
\hline VAR00002 & .405 & .575 & -.077 & .602 & .272 \\
\hline VAR00003 & .025 & .029 & .028 & -.054 & .983 \\
\hline
\end{tabular}

We name the common factors according to its specific meaning determined by the rotated component matrix table. In year 2013, common factors "F1" has great loading in deposit share, loan share, total assets share, fee and commission income growth rate and percentage of bachelor or above employee, so we define "F1" as market ability and innovation ability factor. By the same token, "F2" is defined as growth factor, "F3" is defined as profitability factor, "F4" as liquidity factor, "F5" as profitability factor.

\section{B. Analysis of Test Results}

The final score of the competitiveness is calculated by common factors score multiplied by the corresponding weight, the weight is the variance contribution rate of each common factor.

\section{1) Comprehensive ranking analysis}

By the comprehensive ranking from 2011 to 2013, we can see that the top four are respectively Industrial and Commercial Bank of China, China Construction Bank, Agricultural Bank of China 、 Bank of China, China Minsheng Bank and China Merchants Bank is at five and six respectively, city commercial banks are overall at last ranking. In general, the comprehensive competitiveness of state-owned commercial banks had remained the strongest.

\section{2) Specific factor analysis}

From the point of market ability and innovation ability factor, ICBC、CCB、BOC and $\mathrm{ABC}$ always maintained the highest score, ranked the top three, had the largest market share. In joint-stock commercial banks, CMBC and CMB had the biggest market ability and innovation ability competition, and both of them had this advantage stably. In addition to year 2013, all joint-stock commercial banks' deposit and loan had ascended except that CMB's deposit had $0.01 \%$ declined and CIB's loan had $0.07 \%$ declined.

As for Innovation ability factor, we discuss it from the proportion and growth rate of fees and commissions revenue. State-owned commercial banks were in the front rank for this three years, but theirs growth rate were the lowest, the rate was even appeared a negative growth in 2012. On the contrary, although the fees and commissions revenue of joint-stock commercial banks were lower than state-owned commercial banks', theirs growth rate were the biggest. CMBC's fees and commissions revenue proportion ranked number 1 in 2013, was $28.53 \%$. CEB ranked 2, was $24.14 \%$. In addition, $\mathrm{HXB}$ and CIB's proportion increased year by year.

In terms of profitability factor, CMBC、CMB、CIB and ICBC always had the highest score, the profitability of CMBC and CMB was the strongest, CIB ranked fourth in 201 to third in 2013. The ranking of GDB had a modest improvement ever year, but CEB and CCB had declined. joint-stock commercial banks had an excellent profitability as a whole, but lack of stability.

From the point of growth factor, $\mathrm{HXB}$ and $\mathrm{CMBC}$ ranked among the top two in 2011, 2013 were CMBC and CEB, which means these three banks' total assets and operating profits grew fast, had good growth ability. In general, almost all joint-stock commercial banks' operating profits were growing significantly.

For liquidity factors, $\mathrm{CCB}$ and $\mathrm{CMB}$ get highest score, which means they paid attention to the liquidity management of assets, so had smaller liquidity risk. In joint-stock commercial banks, CMB and China CCB had good liquidity, the liquidity of GDB and HXB was poorer, need to guard against liquidity risk.

\section{CONCLUSIONS AND SUGgestions}

This paper establishes the competitiveness evaluation index system of China's listed commercial banks, bases on the factor analysis to compare the competitiveness of jointstock commercial bank and state-owned commercial banks and city commercial banks in five aspects, and analyzes the longitudinal changes of joint-stock commercial banks. The results indicate that in terms of scale and market share, jointstock commercial banks can't compete with state-owned commercial banks, but theirs growth rate of innovation ability, growth ability, profitability has excellent performance. In these three years the innovation ability of most of the joint-stock commercial banks has been improved, growth ability and profitability were increased year by year. Aiming at the shortcomings of the joint-stock commercial banks have shown, we put forward some suggestions as following:

\section{1) Develop intermediary business vigorously}

From the above analysis we can see that market ability and innovative ability are the key factors that decide the competitiveness of commercial banks, it is unreliable to increase market share to enhance the competitiveness of joint-stock commercial banks in the short term, but 
enhancing innovation capability is realizable. From the point of view, most large banks abroad more than half of their revenue is made up of intermediate business income. Instead, the operating income of China's banking industry is still mainly come from the traditional lending business, intermediate business income do not exceed $30 \%$ at most.

In order to develop the intermediate business of China's joint-stock commercial banks, first of all, bank should set up the concept of developing intermediary business vigorously. Most banks regard developing intermediary business as a method to attract customers and win more customers resources, but not taking serious attention to the long term meanings of developing this business. In terms of choice of business, the bank should focus on developing private banks and consulting business which have great profit space. For intermediary business innovation, joint-stock commercial banks can use financial derivatives and Internet to Innovative products and channels.

\section{2) Introduce and train comprehensive talent}

It can be seen that joint-stock commercial bank's staff most are highly educated workers, but most of them are single knowledge-based, which cannot adapt to the longterm development of the bank. Intermediary business involves finance, law, management, computer and other fields, which require interdisciplinary talents proficient in these areas. For example, investment and financing involves many areas of knowledge, which need a man can master of investment, securities, insurance, foreign currency at the same time. So, comprehensive talent has significant importance to enhance the competitiveness of commercial banks.

\section{REFERENCES}

[1] Yang Jiacai. The Research of Commercial Banks' Competitiveness [J]. Financial research, 2008(12):147-163

[2] Loretta,J.Mester. A Study of Bank Efficiency Taking into Account Risk-preferences [J].Journal of Bank \& Finance, 1996, 20(6):10251045

[3] Joaquin, Maudos, Francisco Perez, and Jose M.Pastor. Cost and Profit Efficiency in European Banks [J].Journal of International Financial Markets, Institutions and Money,2002,12(1):33-58

[4] A,Dietrich, and Wanzenried G. Determinants of Bank Profitability Before and during the Crisis: Evidence from Switzerland [J].Journal of International Financial Markets Institutions and Money,2001, 21(3):307-327

[5] Wang Jiquan, Liu Quanshegn, Zhang Yanyan. the empirical analysis of listed banks in China [J] Financial research,2005(12):96-106

[6] CHI Guotai, ZHENG Xingguo, YANG Zhongyuan. Competitiveness Evaluation of Chinese State-owned Commercial Banks Based on Principal Component Analysis [J]. Chinese Journal of Management, 2009(2):228-233

[7] Fang Xianming, Su Xiaojun, Sun Li. The Invesetigation of the Competitiveness Level of Chinese Commercial Banks: Based on the Empirical Evidence of 16 Listed Commercial Banks from 2010 to 2012 [J]. Financial Securities,2013(2):31-38

[8] LI Quan, YIN Wenjuan A Tentative Analysis on the Competitiveness of Chinese Listed Commercial Banks [J].Journal of Taiyuan University of Technology(Social Sciences Edition), 2013(3):10-33
[9] CHI Guotai, DONG Hechao, YANG De, LIU Yifang. AHP-based Evaluation for the competitiveness of State-owned Commercial Bank [J].Chinese Journal of Management, 2005(6) 